
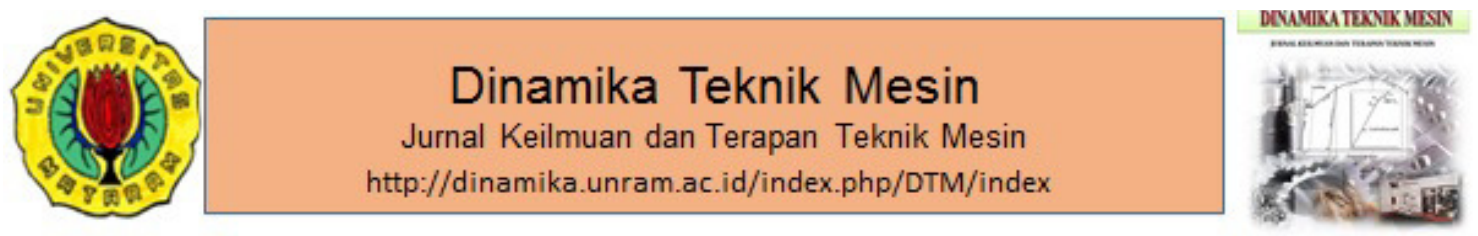

\title{
Design and simulation of boat pulling system to improve productivity of the traditional fishermen in steep coastal region
}

\author{
I.G.N.K Yudhyadi*, I.D.K. Okariawan, I.M. Suartika, I.G.A.K.C Adhi \\ Jurusan Teknik Mesin Fakultas Teknik Universitas Mataram, Jln. Majapahit No. 62 Mataram, Nusa \\ Tenggara Barat, 83125, Indonesia. HP. 085239201951 \\ *Email: ngurah.yudhyadi@unram.ac.id
}

\section{ARTICLE INFO ABSTRACT}

Article History:

Received 17 November 2018

Accepted 4 Desember 2018

Available online 1 January 2019

Keywords:

Traditional fisherman

Effectivness and efficiency

Boat pulling system

Steep coastal

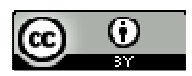

The Indonesian coastal line is the largest in the world and has potentially large number of coastal natural resources, such as fish, seaweed etc. However, the Indonesian fishermen, particularly the traditional ones, have always been facing the hard and mediocre life. The situation was derive a specific research whit long-term goal was an attempt to facilitate the traditional fishermens with better tools in order to increase their income. The specific target was designation and implementation of simple and applicable small boat pulling apparatus to cut down the time needed to move the fishing boat on and off shore. It is no doubth that the introduction of the tool will improve the fishermen operation effectiveness and efficiency. Furthermore, the execution of ideas, manual calculation and raw design drawing along with Autodesk Inventor simulations software has been able to produce a model assembly of boat pulling apparatus. The design prerequisite was based on the results of comprehensive series of surveys related to the West Nusa Tenggara coastal conditions which was steep coastal with slope of 15-30 degrees as well as the simplicity of design needed by the fisherman. Based on the results of static analyse with finite element analysis (FMA) and dinamic analysis, the resulting design meets the shafety design requirements. Finally, the design can be said in the safe category and can be used safely in such conditions without harming the fisherman. Finally, this apparatus will economically improve the fishermen traditional life.

Dinamika Teknik Mesin, Vol. 9, No. 1, Januari 2019, p. ISSN: 2088-088X, e. ISSN: 2502-1729

\section{INTRODUCTION}

Indonesia is known as Maritime State because of its territory that is an archipelago with more than $81,000 \mathrm{~km}$ of coastal line and approximately 17.504 small islands amongst larger islands that have been previously known, spread throughout the country (Ministry of Home Affairs), Arman (2000). Among them, it is around 10.160 islands have been verified. The Indonesian Maritime has huge costal 
Dinamika Teknik Mesin. Yudhyadi dkk.: Design and simulation of boat pulling system to improve productivity of the traditional fishermen in steep coastal region

potential. By 2007 and 2008, its contribution to Indonesian income was rise steeply from $\$ 2,3$ billion to $\$ 2,6$ billion and continue rising to the recent years. The Indonesian maritime and fishery potential has reaches 70 percent of whole Republic of Indonesia territory. It was logic both economically and politically that if the field has becoming the main backbone of national economic development (Miraza, 2009).

The Indonesian traditional fisherman has been always connected with poor and poverty. The picture is describing how poor the life of traditional fishermen. Despite the great potential of the Indonesian coast and sea with the largest ocean in the world, the lives of traditional fishermen are indeed difficult. Poverty of the traditional fishermen occurs mostly caused by lack of efficiency and effectiveness within their activities. Unproductive fishing operations caused by several factors. Those are fishing equipment which is still conventional, high price of fuel, and the condition of the steep coast. The steep coastal condition will require lot of energy to move the boat on and off shore. Besides power, this condition also makes fishermen can not do the job alone at any time.

Ineffectively and inefficiency of the operations of steep coastal fishermen was due to geographic conditions between sea and maind land. The average reach was 2 meters height. So that the process of displacement boat in and of shore of approximately 20 meters distance was time consuming and costly. The operational costs will affect the total productivity of fishermen (Gaspersz, 1998).

Traditionally, the fishermen use force to pull the boat to the mainland or otherwise leave the boat in the water with high maintenance costs or risk of damage to the boat due to big waves. Therefore, the objectives of the recent study are how to design, create, and implement the boat pulling apparatus so that the moving fishing boat can be effectively and efficiently done on and off shore with less effort.

\section{METHODE}

This research is an applied research with descriptive conclusive method with case studies of fishermen operation on the steep coast region in Lombok Island. Product design of the apparatus was developed by using of descriptive design model, included exploration, generation of design alternatives, evaluation of the design concept and discussion of the design based on heuristics solution (experiences, and the rule of thumb). The design produced than calculated, drafted and tested with Inventor software simulatuion from Autodesk.

\section{RESULT AND DISCUSSION}

\subsection{Main requirement}

From the result of the survey and previous research, boat pulling apparatus that will be developed has characteristics and performances as follows (Suartika dkk., 2011):

1. Compact and lightweight but strong.

2. Long-lived with no maintenace although operated in marine environment.

3. Can be driven manually or use the electric motor.

4. Have low pulling speed $(0.1 \mathrm{~m} / \mathrm{s})$ so as not to damage the boat.

5. Rope span approximately 25 meters.

6. Maximum load of 3 tons.

Based on the above specifications, the boat pulling system design consists of several parts as described below:

1. Multi-level speed. This allows a reduction in the energy required to pull the boat and when using of electric motor can be used less power motor.

2. The level of the first speed used v-belt allowing the slip at the first pull-drawn or if the load exceeds the maximum limit.

3. The gears are used for the next-level speed for maximum transmission torque capability and reliability of the system.

4. Shaft, frame, drum, gears and other support equipment is made from stainless steel alloys if possible.

5. The rope used is of the type Nylon rope that does not need treatment.

6. Use bearing that already lubricated and coated and safe from sea water corrosion.

\subsection{Design of the system load sizing}

All system components are calculated based on the load to be pulled which is heavy boat with conditions such as follows:

1. The slope of shore $30^{\circ}$

2. The friction coefficient of sand and the bottom of the boat 0.50 (Wahyudi, 2012) 
Dinamika Teknik Mesin. Yudhyadi dkk.: Design and simulation of boat pulling system to improve productivity of the traditional fishermen in steep coastal region

3. Acceleration of gravity $9.8 \mathrm{~m} / \mathrm{s}^{2}$.

4. The maximum boat weight 3 tons

Based on the above working condition, the forces were calculated based on the following figure:

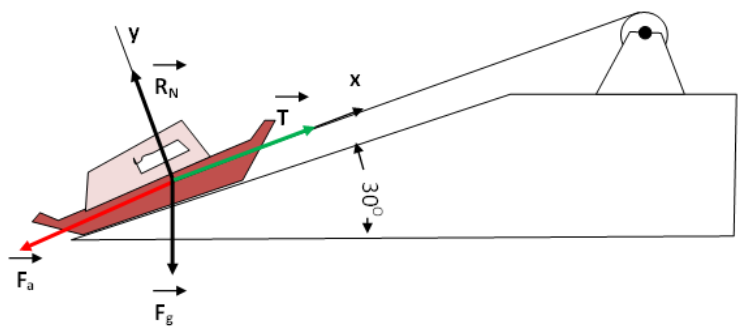

Figure 1. Diagram of the forces acting on the boat

According to figure 1 , the maximum stress that can be supported by the rope can be calculated as follows (Cabral, 2013):

$\sum \overrightarrow{F x}=0$

$-\overrightarrow{F G}-\overrightarrow{F_{g}}+\vec{T}=0$

$\overrightarrow{\bar{T}}=\overrightarrow{F a}+\overrightarrow{F_{g}}$

$\sum \overline{F y}=0$

$\overline{P_{V}}-\overline{F_{g}^{v}}-0$

$\overline{P_{N}}=\frac{\overrightarrow{F_{g}^{y}}}{F^{y}}$

Applying of $50 \%$ of safety factor that allow misuse and small overloaded of devices, the total torque is calculated as follow:

$T^{\prime}=3000 \times 9.8 \times \sin (60) \times 0.5+3000 \times 9.8 \times \cos (60)$

$T=27422.937 \times 1.5=41134.41 \mathrm{~N}=42 \mathrm{kN}$

\subsection{Sizing of components}

The selection of wire rope was based on manufacturer catalogue (Noble and Son, 2011). The catalogue also gives guidance in selection and calculation of roller drum. By following the catalog, then the selected rope was 3 strands Nylon Rope types FNY14 with $14 \mathrm{~mm}$ in diameter (Table 1).

Table 1. Rope standard table (Noble and Son, 2011)

\begin{tabular}{ccccc}
\hline Stock code & $\begin{array}{c}\text { Diameter } \\
(\mathrm{mm})\end{array}$ & $\begin{array}{c}\text { Weight } \\
(\mathrm{kg} / 100 \mathrm{~m})\end{array}$ & $\begin{array}{c}\text { Minimum breaking force } \\
\mathrm{kg}\end{array}$ & $\mathrm{kN}$ \\
\hline FNY10 & 10 & 6.2 & 2.130 & 20.0 \\
FNY12 & 12 & 8.9 & 3.040 & 29.8 \\
FNY14 & 14 & 12.2 & 4.180 & 41.0 \\
FNY16 & 16 & 15.8 & 5.380 & 52.8 \\
FNY18 & 18 & 20.0 & 6.880 & 67.5 \\
\hline
\end{tabular}

Based on calculation of wire rope diameter and counting the number of bends experienced by rope during its work, it can be determined the diameter of the drum. The calculation below was based on mechanical design (Budynas-Nisbett, 2006). Figure 1 shows that the number of bends experienced by rope is equal to 1 and table 1 indicates that the amount of $D_{\min } / d$ is equal to 16 (where $D_{\min }$ is the minimum diameter of the spindle drum and $d$ is the diameter of the rope). $D_{\min }=225 \mathrm{~mm}$ or it is taken as $250 \mathrm{~mm}$. The length of the rope span used is $25 \mathrm{~m}$ and the diameter of the roller drum is $0.25 \mathrm{~m}$, the number of turn can be calculated as follows: number of turn is equal to rope span divided by the drum parameter $(25 / 0.79=31.8 \sim 32$ turn. The drum width is equal to number of turn multiplied by the rope diameter. It is $0.45 \mathrm{~m}$. Flange drum diameter is calculated using equation (3). 
Dinamika Teknik Mesin. Yudhyadi dkk.: Design and simulation of boat pulling system to improve productivity of the traditional fishermen in steep coastal region

$$
\begin{aligned}
& \text { Ropespan }=L_{\text {Drum }}\left(\phi_{\text {flange }}^{2}-\phi_{\text {Drum }}^{2}\right) / 15.3 \phi_{\text {Rope }}^{2} \\
& \phi_{\text {flange }}=0.5 \mathrm{~m}
\end{aligned}
$$

The torque experienced on the rope drum to pull the load can govern from the tensile stress on the ropes and the diameter of the drum which was $0.25 \mathrm{~m}$. The moment on drums was estimated as torque on the rope multiplied by the drum diamter and divided by 2 . It is approximately of $5.125 \mathrm{kNm}$.

\subsection{Compilation of the design}

According to the above calculation, all remaining components is govern. Table 2 depicts the resumes of all components of boat pulling system with all dimension, material and load. Figure 2 shows the complete design.

\begin{tabular}{|c|c|c|c|c|c|}
\hline Tranmission & Belt & RG TK1 & RG TK2 & RG TK3 & RG TK4 \\
\hline \multicolumn{6}{|l|}{ Rotation (RPM) } \\
\hline Input & 50 & 28 & 5.75 & 1.18 & 0.24 \\
\hline Output & 28 & 5.75 & 1.18 & 0.24 & 0.05 \\
\hline \multicolumn{6}{|l|}{ Torrque ( $\mathrm{N} \mathrm{m})$} \\
\hline Input & 5 & 8.932 & 39.122 & 190.508 & 928.34 \\
\hline Output & 8.309 & 39.122 & 190.508 & 928.34 & 5125 \\
\hline Power (W) & & & & & 26.19 \\
\hline Module (m) & & 4 & 4 & 4 & 7 \\
\hline Width (b) $\mathrm{mm}$ & & 15 & 15 & 30 & 35 \\
\hline Press angle & & & & & \\
\hline $\begin{array}{l}\text { (degree) } \\
\text { Jarak sumbu }\end{array}$ & & 20 & 20 & 20 & 20 \\
\hline poros $(\mathrm{mm})$ & & 176 & 176 & 176 & 308 \\
\hline Tangential Force & & & & & \\
\hline $\begin{array}{l}\text { (Ft) } \mathrm{N} \\
\text { Radial Force (Fr) }\end{array}$ & & 297.733 & 1449.833 & 7064.99 & 19849.26 \\
\hline $\begin{array}{l}\mathrm{N} \\
\text { Normal Force }\end{array}$ & & 108.366 & 527.696 & 2571.446 & 7224.539 \\
\hline $\begin{array}{l}\text { (Fn) N } \\
\text { Number of Teeth }\end{array}$ & & 316.841 & 1542.879 & 7518.406 & 21123.14 \\
\hline (Z) Input & & 15 & 15 & 15 & 15 \\
\hline Output & & 73 & 73 & 73 & 73 \\
\hline $\begin{array}{l}\text { Meterial } \\
\text { Input }\end{array}$ & $\begin{array}{l}\text { Carbon Struct, Steel } \\
\text { (case hardening) } \\
\text { A576-1015 }\end{array}$ & & & & \\
\hline $\begin{array}{l}\text { Output } \\
\text { Transmision }\end{array}$ & А322-4340 & & & & \\
\hline $\begin{array}{l}\text { Ratio (i) } \\
\text { Diameter of }\end{array}$ & 1.79 & 4.86 & 4.86 & 4.86 & 4.86 \\
\hline Teeth Input & 146 & 60 & 60 & 60 & 105 \\
\hline Dout & 247 & 292 & 292 & 292 & 511 \\
\hline
\end{tabular}

Table 2. Compilation of components of system 
Dinamika Teknik Mesin. Yudhyadi dkk.: Design and simulation of boat pulling system to improve productivity of the traditional fishermen in steep coastal region

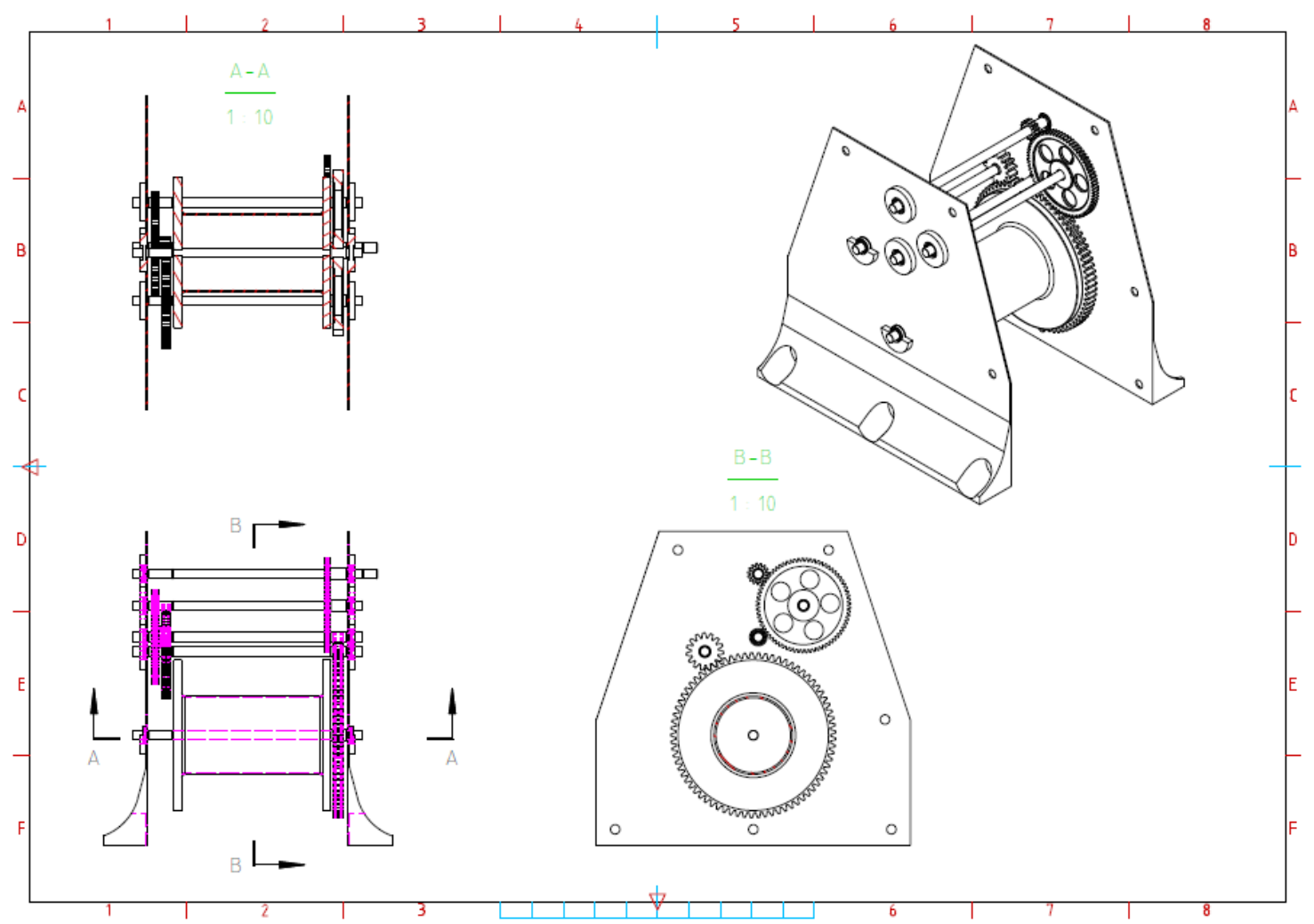

Figure 2. Complete design

\subsection{Discusion}

To determine the design feasibility, it is necessary to analyse the strength of elements of the transmission system due to load applied. To do so, Autodesk Inventor Software provides tools to simplify the analysis. The following is a review conducted on multiple components of the boat transfer planning tool.

\section{6 simulation of gear terrain}

The Von mises stress criteria (figure 3 ) is used to determine the feasibility of a design. The Von Mises stress occures at $1224 \mathrm{MPa}$. This indicates that the material is still able to transmit the torque, which is lower than the yield stress of the material.
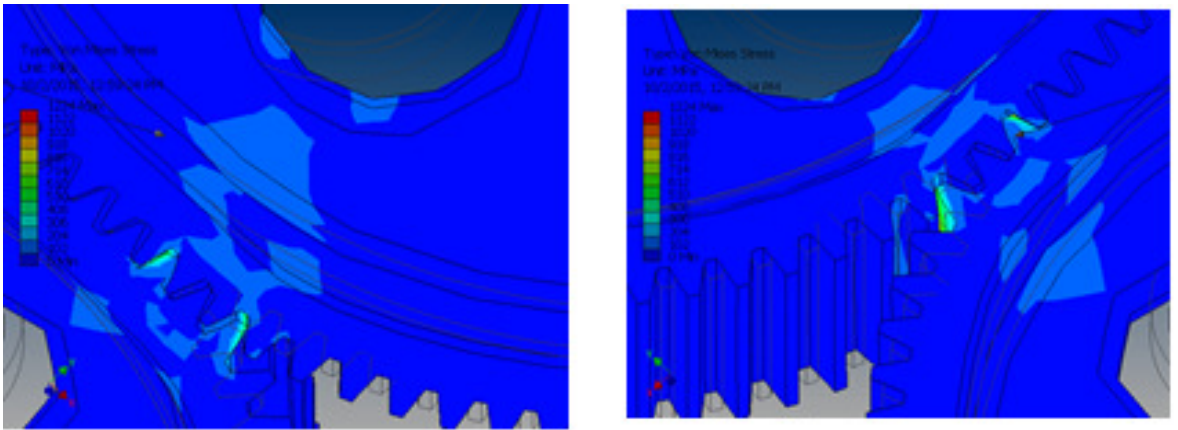

Figure 3. The von mises stress criterion

Furthermore, the safety factor (figure 4) is calculated by dividing the von mises stress criterion by the yield stress of materials. The simulation result shows that the safety factor ranges from 0.17 to 15. This means that the material is still within the safe limits in its operations. 
Dinamika Teknik Mesin. Yudhyadi dkk.: Design and simulation of boat pulling system to improve productivity of the traditional fishermen in steep coastal region

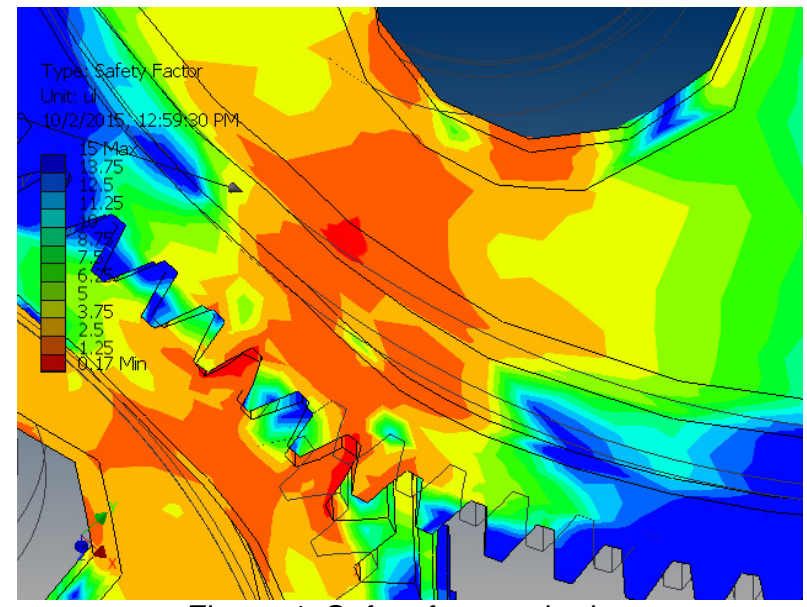

Figure 4. Safety factor criterion

\subsection{Simulation of shaft}

Configuration of simulated shaft is shown in figure 5 with all parameters used. The rsults of the simulation are shown in figure 6, 7, 8 and 9 for shear force diagrams, moments, deflection angle and displacement consecutively.

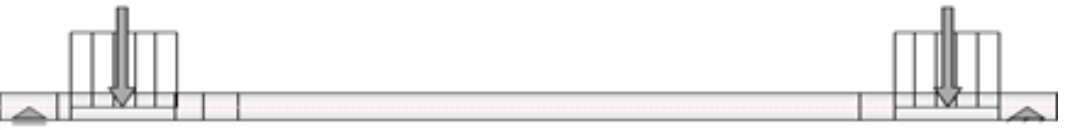

Figure 5. Cofiguration of simulated shaft
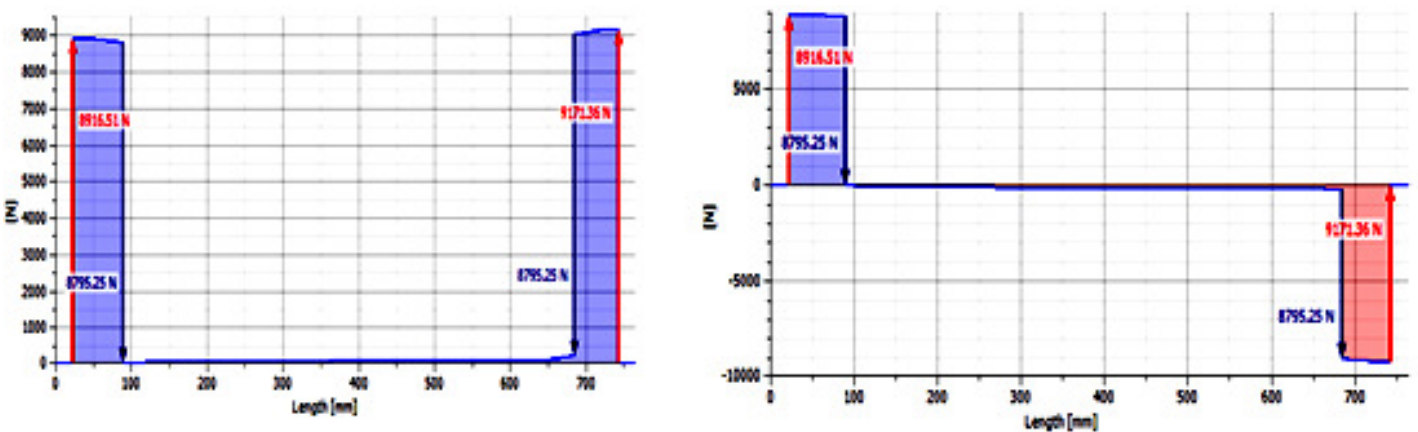

Figure 6. Shear stesss on $X Y$ and $Y Z$ plane
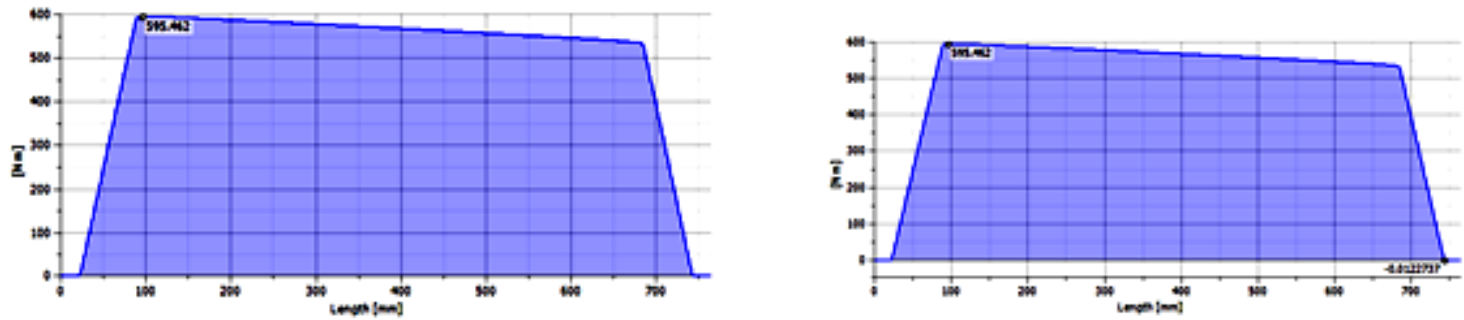

Figure 7. Bending moment on $X Y$ and $Y Z$ plane 

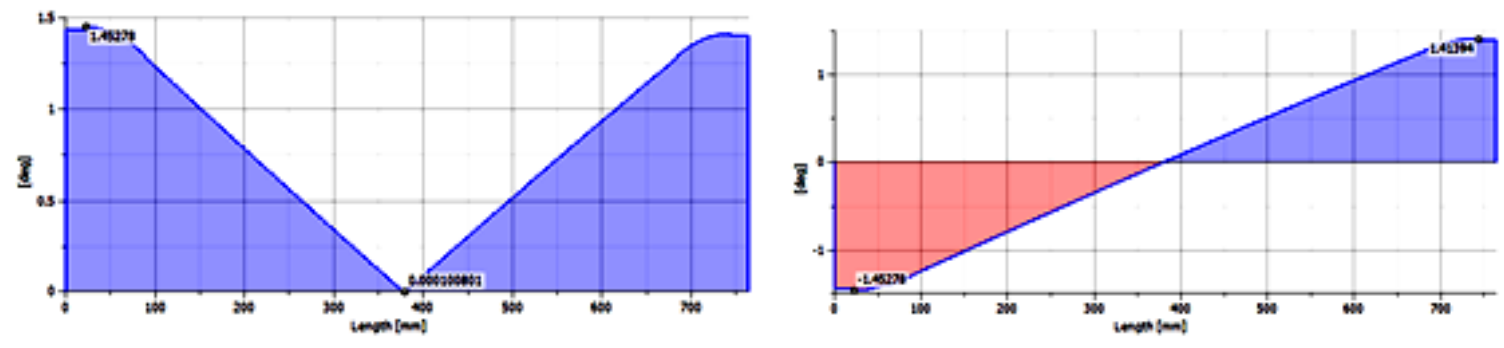

Figure 8. Deflection angle on $X Y$ and $Y Z$ plane
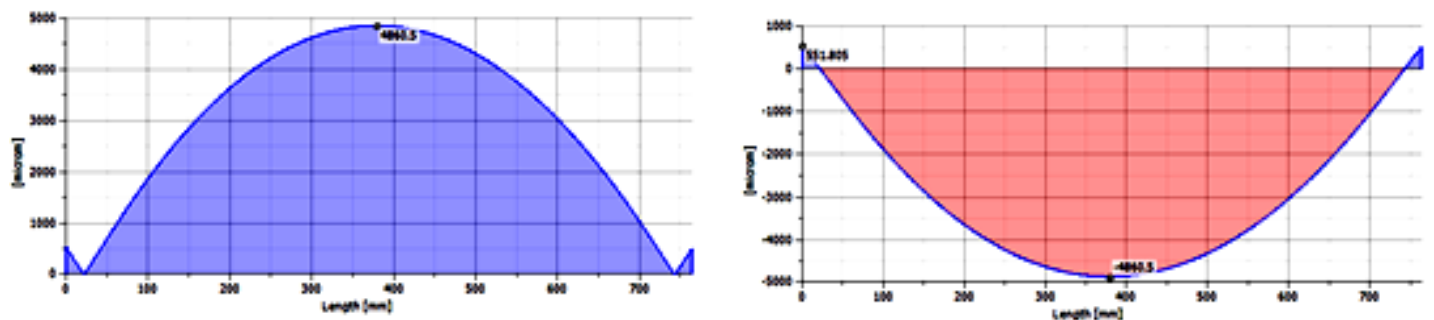

Figure 9. Displacemen on $X Y$ and $Y Z$ plane

Figures 6 through 8 elucidate that the greatest shear force is equal to $9171.36 \mathrm{~N}$ in XY plane. Meanwhile, the greatest moment is $595.461 \mathrm{Nm}$ and the largest deflection angle is 1.452 degree respectivelly. Based on the bending stress and tensile stress, the maximum bending moment is 224.6 $\mathrm{Nm}$ and the tensile stress is $16.8 \mathrm{MPa}$ (see figure 9). It can be concluded that the shaft design is meet the design specification.
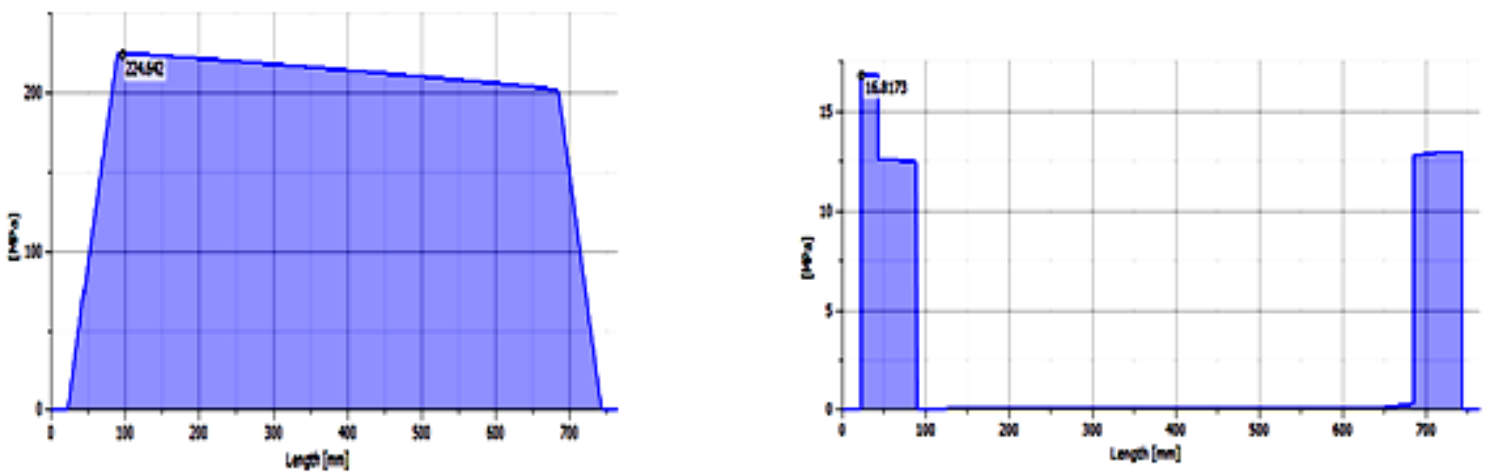

Figure 10. Bending strees and stress strain

\subsection{Simulation of the roller drum}

The result of drum roller simulations is depicted in figure 11.
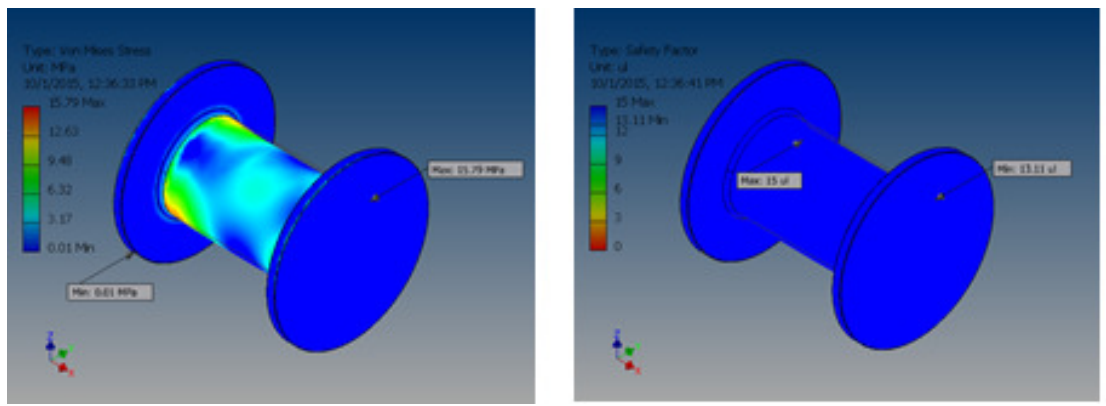

Figure 11. Von mises diagram and safety factor for rolling drum 
Dinamika Teknik Mesin. Yudhyadi dkk.: Design and simulation of boat pulling system to improve productivity of the traditional fishermen in steep coastal region

The result of the simulation (figure 11) shows that the von mises stress occurring is equal to 10 $\mathrm{MPa}$ and the safety factor is 13:11-15 respecivelly. This indicates that the drum meet the design requirement.

\section{CONCLUSION}

From the beginning of the design, calculation and development of boat pulling apparatus, some remarks can be concluded that the process from concept to calculation of mechanical systems of boat pulling syatem is highly depending on its natural operating conditions including slope of inclination, friction factor of the beach sand and ease of use. These factors allow the designer to determine the initial conditions of the system, mechanical components, dimensions and its characteristics. The results of Autodesk Inventor simulation can be used to determine the operational feasibility of the boat pulling apparatus. The result shows that the apparatus is safe and able to overcome the operating condition.

\section{REFERENCES}

Arman N., 2000, Perencanaan dan pengendalian produksi, Guna Widya, Jakarta.

Budynas-Nisbett, 2006, Shigley's mechanical engineering design, 8th edition, McGraw Hill.

Cabral P.F, 2013, Traction winch-design, calculation and analyses, Departamento de Engenharia Mecanica ISEL, http://www.otrimaran.blogspot.com (diunduh 1 Januari 2014).

Gaspersz, 1998, Metode analisis untuk peningkatan kualitas, Gramedia Pustaka Utama, Jakarta.

Noble A., Son, 2011, Word class lifting solution, fibre rope, www.nobles.com.au.

Miraza R., 2009, Implementasi program pemberdayaan ekonomi masyarakat pesisir (PEMP) di Kecamatan Tanjung Pura Kabupaten Langkat,Tugas Akhir, Universitas Sumatra Utara, Sumatra Utara.

Suartika I.M., 2011, Perancangan alat angkat perahu "Campur Dorong" untuk meningkatkan efisiensi dan efektifitas operasional nelayan pada pesisir pantai curam, Laporan Penelitian DPP/SPP, Lemlit Unram, Mataram.

Wahyudi Y., 2012, Perbandingan mortar berpasir pantai dan sungai media teknik sipil, 10(1), 70-79. 